\title{
前庭神経炎症例に和ける中枢障害所見の検討
}

\author{
今手 祐二・関谷 透 $\cdot$ 大上麻由理 $\cdot$ 三浦 正子
}

\section{Signs of Central Nervous System Disorders in Vestibular Neuronitis}

\author{
Yuji Imate, Toru Sekitani, Mayuri Okami, Masako Miura \\ Department of Otolaryngology, Yamaguchi University School of Medicine
}

Equilibrium and audiological examinations were conducted in 73 patients with a diagnosis of vestibular neuronitis during 1972 and 1993. In 23 patients central nervous system disorders were suspected from the results of tests of positional and positioning nystagmus, smooth pursuit, optokinetic nystagmus or auditory brainstem response. In this group of patients the mean age and the frequency of associated disorders and vertigo (dizziness) were significantly higher than in other patients, and the time intervals between the onset and improvement or disappearance of vertigo, nystagmus and canal paresis were longer. These findings suggest that aging and associated disorders of the central nervous system increase susceptibility to vestibular neuronitis.

Key words: vestibular neuronitis, central nervous system disorders, aging, associated disorders

\section{はじめに}

一般に前庭神経炎の主な障害部位は末梢前庭, 特に後迷路であると考劣られている。しかし前庭 神経炎の発症原因はいまだ確定されておらず，前 庭神経炎症例において，中枢障害を疑わせる検查 所見を認めたとする報告もある。我々は前庭神経 炎症例のうち中枢障害を疑わせる所見を認めた症 例について，その所見と病因，病態との関係を検 討した。

\section{対 象}

対象は1972年から1993年までの間に, 山口大学 耳鼻咽喉科に扣いて診断・加療を受けた前庭神経 炎73症例である。

\section{方 法}

対象症例に括いて, 経過観察期間中, 中枢障害

山口大学医学部耳鼻咽喉科学教室
を疑わせる検査所見の有無を検討した。調査した 項目は平衡機能検査では頭位・頭位変換眼振, ETT 及び OKP，聴覚検査ではABR である。頭 位・頭位変換眼振検查では複数の頭位にて垂直あ るいは垂直成分を含む眼振を認めた場合を異常所 見陽性とした。ETT, OKP 検査はいずれも自発 眼振消失後の検査にて判定し, 眼運動の方向に関 保なく異常（ETT 検查では階段状や失調所見， OKP では中央抑制所見を異常と判定した）を認 めた場合，また ABR では I-V 波間潜時 $4.4 \mathrm{msec}$ 以上を異常所見陽性と判定した。その結果73例中 23例に拉いて上記 4 項目の5ちいずれかの異常を 認めた。異常所見を認めた23症例（以下 C 群) と認めなかった50症例（以下 P 群）を比較した。 比較検討項目は合併症（めまいに関連があると推 定される高血圧, 桾尿病, 心疾患, 脳循環障害な ど), 浮動性めまい, 随伴症状 (眼前暗黒, 頭痛, 
表 1 検討項目

\begin{tabular}{|l|c|c|c|}
\hline 検討項目 & $P$ 群 $(n=50)$ & $C$ 群 $(n=23)$ & カイ2乗検定 \\
\hline 合併症 & $4(8)$ & $6(26)$ & $*$ \\
\hline 浮動性めまい & $3(6)$ & $5(22)$ & $*$ \\
\hline 眼前暗黑 & $1(2)$ & $2(9)$ & N S \\
\hline 頭痛 & $10(20)$ & $4(17)$ & N S \\
\hline 意識障害 & 0 & 0 & N S \\
\hline
\end{tabular}

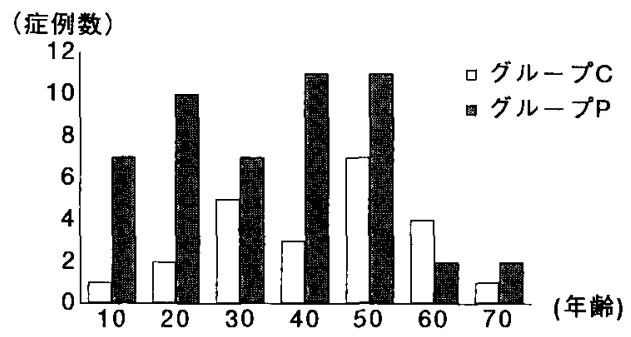

説明：グループCの平均年監 $=47$ 歳、グループPの平均 年齿 $=39$ 虔

図 1 発症年㱓分布

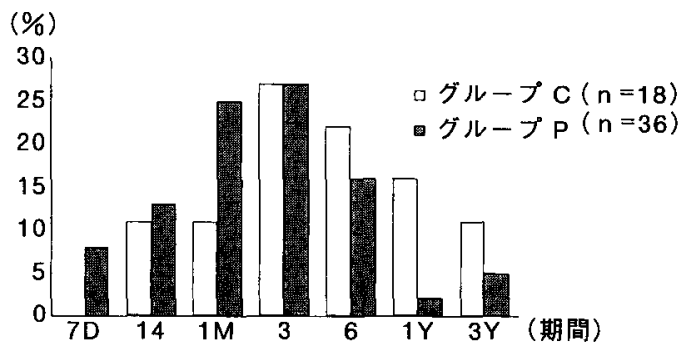

説明；横軸はめまい症状が消失するまでの期間、踶朝は 症例の割合を示す。グルーブСの期間の平均=約5 个月、 グルーブPの期間の平均=䄪9ケ月。

図 2 めまい症状の経過

意識障害）の有無である。めまい症状，眼振，お よび半規管麻疩の発症後の経過についても確認で きた症例について2 群間で比較した。眼振は頭位 ·頭位変換眼振検查所見を, 半規管麻痺は眼振持 続時間または最大緩徐相速度について検討した。

結果

上記各項目について検討する前に，二群間の年 秢分布を比較した。結果は図 1 の如くであり，C 群の平均年齢が P 群に比し有意に高かった。合

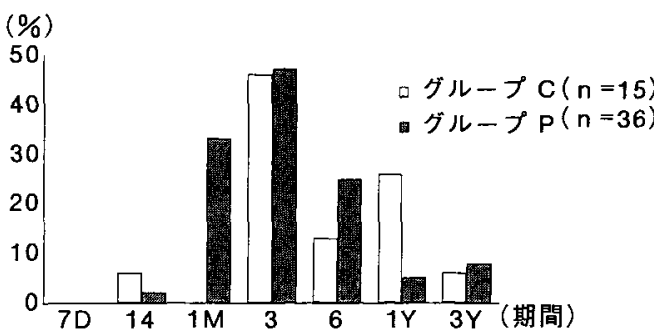

説明；横軸は眼振が消失するまでの期間、綎軸は症例の 割合を示す。

図 3 眼振の経過

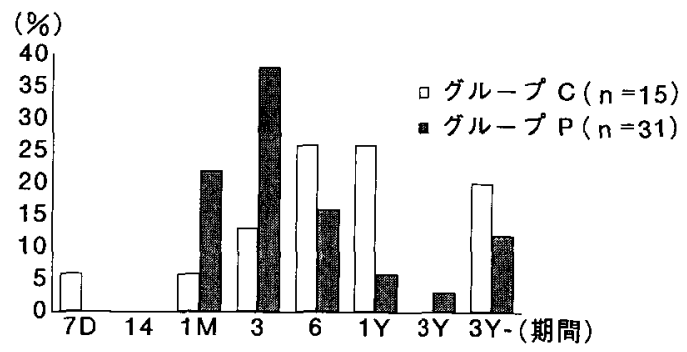

説明；横軸は半規管麻痺が改善または消失するまでの 期間、络軸は症例の割合を示す。

\section{図 4 半規管麻㾝の経過}

併症, 浮動性めまい, 随伴症状（眼前暗黑, 頭痛, 意識障害）に関しては表 1 の如く合併症，浮動性 めまいに拈いて二群間に差を認めたが，随伴症状 に関してはいずれも差を認めなかった。発症後め まい症状が消失するまでの期間を比較すると，図 2 の如くC群に拈いてめまい症状が消失するま での期間が延長する傾向を認奴。眼振に関して は図 3 の如く $P$ 群に比べC 群に打いて 1 年以上 眼振が陽性である割合が高く，半規管麻㽻に関し ては図 4 の如くP群に比べC群に括いて所見が 改善または消失するまでの期間が延長する傾向を 認めた。

\section{考 察}

前庭神経炎にお打る障害部位は，一般には末梢 前庭，特に後迷路が考えられている1)。しかしこ れまでに少数ながら前庭神経炎症例儿扣いて中枢 障害所見を認めたとする報告がある。これらは主 に平衡機能検查から中枢障害を推定した報 
告2) 万) と聴覚検査から中权障害を推定した報 告4) 7) に分けられる。今回用いた眼振，ETT, OKPなどに扣ける中权障害を疑わせる所見は， 必ずしも中枢障害に特異的とはいえないが，一般 的には中权障害時に認められることが多く，前庭 神経炎症例に打いて認められるこの様な平衡機能 検查あるいは聴覚検査上の中枢障害を疑わせる所 見が何を意味するのか知ることを目的として検討 を行った。平均年齢を比較すると，P群に比較し てC 群に和いて平均年龄が有意に高かった。眼 振，ETT, OKP などは年龄の影響を受けるとさ

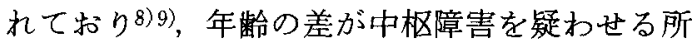
見の発現に影響した可能性は十分に考えられる。 合併症に関しては特にめまいに関連があると推定 される高血圧, 糖尿病, 心疾患, 脳循環障害など について検討したが，P群に比しC群において 合併症の割合が有意に高かった。この結果は以前 我々が報告した前庭神経炎 531 症例に和ける眼振 所見に関寸る検討結果 ${ }^{10)}$ と一致し，中权障害を 疑わせる所見の発現に合併症が関与している可能 性が考兄られる。前庭神経炎症例に捣ける中枢障 害を疑わせる所見は必ずしも前庭神経炎の発症原 因が中枢障害に起ことを意味しないが，発 症時のめまいの性状や随伴症状はめまいの発症原 因と密接な関係を有するものと考学られる。すな わち浮動性めまいや, 眼前暗黒, 頭痛, 意識障害 などの随伴症状はめまいの発症原因が末梢よりは 中枢に存在することを示唆している。今回の検討 では $\mathrm{P}$ 群に比しC群において浮動性めまいの割 合が有意に高かったが，随伴症状に関しては二群 間に差を認めなかった。この結果は前庭神経炎の 原因が末梢前庭の障害であることを否定するもの ではないが，少なくとも一部の症例では発症の原 因となった障害が中权にも及んでいる可能性が考 えられる。前庭神経炎症例のめまい症状, 眼振, 半規管麻痺のいずれに扎いても， P 群に比較して C 群において改善や消失が遅れる傾向を認めた点 に関しては，発症原因としての中枢障害の関与の 可能性も考学られるが，ささにも述べた如く年龄 や合併症が中权障害を疑わせる所見の発現に関与 して和り，それらがさらに前庭代償にも影響を与

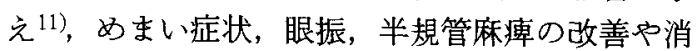
失を遷延化させたものと推定した。

\section{まとめ}

1. 前庭神経炎73症例を中枢障害所見の有無に より群分し，二群を比較した。

2. 中枢障害所見陰性群に比し陽性群において 平均年敹命が有意に高く, 合併症の割合, 浮動性め まいの割合も有意に高かった。

3. 中枢障害所見陽性群に和いてめまい症状, 眼振，半規管麻瘴の改善や消失が遷延する傾向を 認めた。

4. 前庭神経炎の中权障害所見やめまい症状, 眼振，半規管麻㽻遷延化の原因として年齢や合併 症の関与を考兄た。

\section{謝 辞}

本研究は厚生省特定疾患前庭機能異常調査研究 班の研究費援助により行われた。

文献

1) 関谷 透: 前庭神経炎一その臨床像と検査成 績よりする病態の考察一. 山口医学 $31: 107$ $-117,1982$

2) Wennmo C, Pyykkö I: Vestibular neuronitis - a clinical and electro-oculographic analysis-. Acta Otolaryngol (Stockh) 94 : 507515,1982

3) Ishikawa K, Edo M, Togawa K: Clinical observation of 32 cases of vestibular neuronitis. Acta Otolaryngol Suppl (Stockh) 503 : 13-15, 1993

4) Corvera J, Davalos RL: Neurotologic evidence of central and peripheral involvement in patients with vestibular neuronitis. Otolaryngol Head Neck Surg 93 : 524-528, 1985

5) Haid T, Mirsberger J: Die periphere Neuropathia Vestibularis und ein zentralvestibuläres Äquivalent. HNO $33: 262-270$, 1985

6) Bergenius J, Borg E: Audio-vestibular findings in patients with vestibular neuronitis. Acta Otolaryngol (Stockh) $96: 389-395$, 1983

7) Anttinen A, Lang AH, Aantaa E, et al: Vestibular neuronitis; a neurological and neurophysiological evaluation. Acta Neurol 
Scand $67: 90-96,1983$

8) 中川 㹈, 水越鉄理, 渡辺行雄, 他: 高龄者 のめまい，平衡障害の害態（第 2 報）一視運 動性眼振検查に扣ける加齢の影響に関する検 討一. Equilibrium Res 45 : 358-363, 1986

9 ）徳増厚二: 機能検查成績, 年齢之正常値 : 耳 鼻咽喉科・頭頸部外科 MOOK 12. 老年者と 耳鼻咽喉科. 56-64頁, 金原出版, 東京, 1989

10）今手祐二, 関谷 透, 沖中芳彦, 他 : 前庭神 経炎に永ける眼振所見一全国フンケート調査
結果より一. Equilibrium Res Suppl 9:2528,1993

11) Yuji I, Sekitani T: Vestibular Compensation in vestibular neuronitis. Long-term follow-up evaluation. Acta Otolaryngol (Stockh) 113 : 463-465, 1993

$\left(\begin{array}{l}\text { 原稿到着 : 平成 } 6 \text { 年 } 5 \text { 月 } 10 \text { 日 } \\ \text { 別刷請求先 : 今手祐二 } \\ \text { 干755 山口県宇部市小串 } 1144 \\ \text { 山口大学医学部耳鼻咽唉科学教室 }\end{array}\right)$

